\title{
PENERAPAN MODEL PEMBELAJARAN INKUIRI UNTUK MENINGKATKAN AKTIVITAS DAN HASIL BELAJAR SISWA
}

\author{
Putri Tuti Ulansari ${ }^{1 *}$, Irwandi Ansori ${ }^{1}$, Yennita ${ }^{1}$ \\ ${ }^{1}$ Program Studi Pendidikan Biologi, Fakultas Keguruan dan Ilmu Pendidikan, Universitas Bengkulu \\ Email: rohmahanwar71@gmail.com
}

\begin{abstract}
Abstrak
Penelitian ini bertujuan untuk mendeskripsikan aktivitas mengajar guru dan aktivitas belajar siswa serta meningkatkan hasil belajar siswa dalam proses pembelajaran biologi dengan menggunakan model pembelajaran inkuiri di kelas XI IPA 6 SMA Plus Negeri 7 Kota Bengkulu pada materi sistem ekskresi manusia. Jenis penelitian ini adalah penelitian tindakan kelas (PTK) dengan metode deskriptif. Penelitian ini terdiri dari dua siklus. Setiap siklus terdiri atas 4 tahap yaitu tahap perencanaan, pelaksanaan tindakan, pengamatan dan refleksi. Subjek penelitian ini yaitu peneliti sebagai guru dan siswa kelas XI IPA 6 SMA Plus Negeri 7 Kota Bengkulu tahun ajaran 2016/2017. Teknik pengumpulan data dalam penelitian ini yaitu observasi dan tes. Instrument penelitian berupa lembar observasi untuk mengetahui aktivitas mengajar guru dan aktivitas belajar siswa, sedangkan lembar tes digunakan untuk mengetahui hasil belajar biologi siswa. Hasil analisis data aktivitas guru siklus I diperoleh skor rata-rata 19 (cukup), siklus II menjadi 24 (baik). Hasil analisis data observasi aktivitas siswa siklus I diperoleh skor rata-rata 19 (cukup), siklus II menjadi 24 (baik). Selanjutnya data hasil belajar siswa siklus I dianalisis berdasarkan kriteria ketuntasan belajar klasikal dan diperoleh persentase ketuntasan belajar klasikal yaitu $80,56 \%$ yang termasuk kedalam kriteria belum tuntas dan pada siklus II hasil belajar siswa mengalami peningkatan dengan ketuntasan belajar klasikal yaitu $90,67 \%$ dan termasuk dalam kriteria tuntas. Dari hasil penelitian dapat disimpulkan bahwa model pembelajaran inkuiri dapat meningkatkan aktivitas dan hasil belajar siswa.
\end{abstract}

Kata kunci: Aktivitas, Hasil Belajar, Model Pembelajaran Inkuiri, Sistem Ekskresi.

\begin{abstract}
This study aimed to describe the teachers activity and students learning activity and increase the result of students learning in biology learning process used learning model in class XI IPA 6 SMA Plus Negeri 7 Bengkulu city inquiry to human excretion system lesson. This research was Classroom Action Research (PTK) with descriptive method. This research consist of 2 cycle. Each cycle contain of 4 steps, planning, action, observation and reflection. Subjects of this research were teacher and all of students in class XI IPA 6 SMA Plus Negeri 7 Bengkulu city period 2016/2017. The data for this research was coflected log observation and test. The research instruments were observative papers to determined the result of students learning, and test papers to determined biology learning result. The result analysis showed teachers activity for first cycle was average score 19 (enough), second to 24 (good). The result of students learning in cycle 1 was analized based on criteria learning complete classical is about $80,56 \%$ in uncomplete criteria and for cycle II result of students learning ara increase with complete criteria is $90,67 \%$. The conclusion from this research were inquiry learning could increase the teachers activity, students activity and the result of students learning.
\end{abstract}

Keywords: activity, learning result, inquiry learning model, and excretion system. 


\section{PENDAHULUAN}

Pendidikan merupakan proses pembelajaran dimana peserta didik menerima dan memahami pengetahuan sebagai bagian dari dirinya dan kemudian mengelolahnya sedemikian rupa untuk kebaikan dan kemajuan bersama. Pendidikan yang dimaksud bukanlah berupa materi pelajaran yang didengar ketika diucapkan, dilupakan ketika guru selesai mengajar dan baru diingat kembali ketika masa ulangan atau ujian datang. Namun sebuah pendidikan yang memerlukan proses yang bukan saja baik tetapi juga asyik dan menarik baik bagi guru maupun siswa (Anam, 2016).

Kurikulum 2013 yang diberlakukan mulai tahun ajaran 2013/2014 merupakan pengembangan dari kurikulum yang telah ada sebelumnya, baik kurikulum berbasis kompetensi yang telah dirintis pada tahun 2004 maupun kurikulum tingkat satuan pendidikan pada tahun 2006. Hanya saja yang menjadi titik tekan pada kurikulum 2013 ini adalah adanya peningkatan dan keseimbangan soft skills dan hard skills yang meliputi aspek kompetensi sikap, keterampilan, dan pengetahuan (Fadlillah, 2014).

Dalam Undang-Undang nomor 20 tahun 2003 menjelaskan bahwa pendidikan nasional bertujuan mengembangkan potensi peserta didik agar menjadi manusia yang beriman dan bertakwa kepada Tuhan Yang Maha Esa, berakhlak mulia, sehat, berilmu, cakap, kreatif, mandiri, dan menjadi warga negara yang demokratis serta bertanggung jawab (Kurniasih, 2014).

Berdasarkan hasil observasi dan wawancara dengan guru biologi yang juga menjadi wali kelas XI IPA 6 SMA Plus Negeri 7 Kota Bengkulu. Permasalahan pembelajaran yang dapat diidentifikasi dari kelas XI IPA 6 yang terjadi pada guru antara lain: guru jarang sekali menggunakan model pembelajaran inkuri dan dalam kegiatan pembelajarannya guru lebih dominan, dimana informasi banyak disampaikan oleh guru dibandingkan siswa menemukan sendiri.

Diketahui bahwa kriteria ketuntasan minimal (KKM) di sekolah SMA Plus Negeri 7 Kota Bengkulu untuk mata pelajaran biologi adalah $\geq 75$, tetapi masih banyak siswa yang belum mencapai angka ketuntasan tersebut. Berdasarkan data yang diperoleh dari guru biologi bahwa rerata nilai hasil belajar biologi siswa kelas XI IPA 6 hanya 17 orang siswa saja yang tuntas belajaranya dari 36 orang siswa. suatu kelas dikatakan tuntas belajarnya apabila $\geq 85 \%$ siswa telah memperoleh nilai $\geq 75$, hal ini berarti hanya 47,22 \% (17 orang) siswa kelas XI IPA 6 yang tuntas belajar biologi secara klasikal.

$$
\text { Menurut Rusman }
$$

pembelajaran merupakan suatu sistem yang terdiri atas berbagai komponen yang saling berhubungan satu dengan yang lain. Komponen tersebut meliputi: tujuan, materi, metode, dan evaluasi. Keempat komponen pembelajaran tersebut harus diperhatikan oleh guru dalam memilih dan menentukan model-model pembelajaran apa yang akan digunakan dalam kegiatan pembelajaran. Dalam penelitian ini, model pembelajaran yang akan digunakan yaitu model pembelajaran inkuiri, agar lebih melibatkan partisipasi siswa secara aktif dalam menemukan konsep pelajaran, sehingga pengetahuan yang didapat berdasarkan pengalaman itu akan lebih bertahan lama dan bisa meningkatkan hasil belajar siswa yang mencakup 3 ranah yaitu kognitif, afektif, dan psikomotor.

Model Pembelajaran inkuiri (MPI) adalah suatu model pembelajaran yang dikembangkan agar siswa menemukan dan menggunakan berbagai sumber informasi dan ide-ide untuk meningkatkan pemahaman mereka tentang masalah, topik, atau isu tertentu. Penggunaan model ini menuntut siswa untuk mampu untuk tidak hanya sekedar menjawab pertanyaan atau mendapatkan jawaban yang benar. Model ini menuntut siswa untuk melakukan 
serangkaian investigasi, eksplorasi, pencarian, eksperimen, penelusuran, dan penelitian (Abidin, 2014).

Tujuan penelitian ini untuk mendeskripsikan aktivitas guru dan siswa serta meningkatkan hasil belajar siswa dalam proses pembelajaran biologi materi sistem ekskresi dengan menerapkan Model pembelajaran inkuiri di kelas XI IPA 6 SMA Plus Negeri 7 Kota Bengkulu.

\section{METODE PENELITIAN}

Jenis penelitian yang digunakan oleh peneliti ialah jenis penelitian tindakan kelas (PTK) sedangkan metode yang digunakan dalam penelitian ini adalah metode deskriptif. Teknik pengumpulan data yang digunakan dalam penelitian ini ada 2 cara, yaitu dengan observasi dan tes. Pada peneltian ini menggunakan instrumen penelitian untuk observer yaitu lembar observasi dan instrumen penelitian yang digunakan untuk mengukur hasil belajar siswa yaitu lembar tes.

Pada prosedur penelitian menurut Arikunto, dkk (2014) PTK direncanakan dalam dua siklus dan setiap siklus terdiri dari empat tahap yaitu perencanaan, pelaksanaan tindakan, pengamatan, dan refleksi. Teknik analisis data hasil observasi aktivitas mengajar guru dan aktivitas belajar siswa menggunakan rumus sebagai berikut:

1. Rata-rata skor $=\frac{\text { jumlah skor }}{\text { jumlah observer }}$

2. Skor tertinggi $=$ jumlah aspek pengamatan $x$ skor tertinggi setiap aspek

3. Skor terendah = jumlah aspek yang diamati $x$ skor terendah setiap aspek

4. Selisih skor $=$ skor tertinggi - skor terendah

5. Kisaran nilai untuk tiap kriteria pengamat= $\frac{\text { selisih skor }}{\text { jumlah kriteria penilaian }}$ (Arikunto, 2010).

Menurut Sudjana (2011) untuk mengetahui nilai rata-rata hasil belajar siswa maka diperlukan rumus sebagai berikut:

$$
\bar{X}=\frac{\sum X}{N}
$$

Keterangan :

$\bar{X}=$ Nilai rata-rata kelas $\sum X=$ Jumlah nilai siswa keseluruhan

$N=$ Jumlah seluruh siswa

Persentase Ketuntasan Belajar Klasikal menurut Trianto (2011) dapat dihitung dengan menggunakan rumus sebagai berikut:

$\mathrm{KB}=\frac{T}{\mathrm{Tt}} \times 100 \%$

Keterangan :

$\mathrm{KB}=$ ketuntasan belajar klasikal

$\mathrm{T}=$ jumlah siswa yang memperoleh

nilai $\geq 2,67$

$T_{t}=$ jumlah seluruh siswa

\section{HASIL DAN PEMBAHASAN}

Berdasarkan penelitian yang telah dilaksanakan di kelas XI IPA 6 SMA Plus Negeri 7 Kota Bengkulu pada hari Selasa tanggal 17 April 2017 dengan menerapkan model pembelajaran inkuiri sebanyak dua siklus berfokus pada aktivitas mengajar guru, aktivitas belajar siswa dan hasil belajar siswa pada materi sistem ekskresi, diperoleh hasil sebagai berikut:

\section{Deskripsi Hasil Observasi Terhadap Aktivitas Guru dan Aktivitas Siswa pada Model Pembelajaran Inkuiri di Siklus I dan Siklus II}

Pada kegiatan siklus I dan siklus II dilakukan observasi aktivitas mengajar guru dan aktivitas belajar siswa terhadap proses pembelajaran biologi dengan menggunakan Model Pembelajaran Inkuiri yang dilakukan oleh 2 orang pengamat yaitu guru biologi. Hasil dari observasi aktivitas guru dan aktivitas siswa dapat dilihat pada Tabel 1 . sebagai berikut:

Tabel 1. Data Hasil Observasi Terhadap Aktivitas Guru dan aktivitas siswa pada Siklus I dan II

\begin{tabular}{ccc}
\hline Siklus & Pengamat & Skor \\
\hline I & 1 & 19 \\
& 2 & 19 \\
& Total Skor & 38 \\
& Rerata Skor & 19 \\
II & Kriteria & Cukup \\
& 1 & 24 \\
& 2 & 24 \\
& Total Skor & 48
\end{tabular}




\begin{tabular}{cc} 
Rerata Skor & 24 \\
Kriteria & Baik \\
\hline
\end{tabular}

Berdasarkan Tabel 1. Pada siklus I diketahui bahwa perolehan skor dari 2 pengamat adalah sebesar 38 dengan rata-rata skor 19. Rata-rata skor tersebut menunjukkan bahwa aktivitas guru dan aktivitas siswa selama proses pembelajaran pada siklus I sudah termasuk kedalam kriteria cukup. Setelah dilakukan refleksi pada siklus II diketahui bahwa hasil observasi aktivitas guru dan aktivitas siswa menunjukkan terjadinya peningkatan aktivitas guru dan aktivitas siswa dalam proses pembelajaran. Hal ini terlihat dari skor aktivitas guru dan aktivitas siswa dengan menggunakan model pembelajaran inkuiri pada siklus II diperoleh dari pengamat I dan pengamat II ialah 24 dengan total skor dari dua orang pengamat 48 dan rerata skor 24. Rerata skor 24 ini sudah termasuk kedalam kriteria baik.

\section{Deskripsi Hasil Belajar Siswa pada Siklus I dan siklus II}

Hasil belajar mencakup tiga ranah yaitu ranah pengetahuan, ranah keterampilan, dan ranah sikap. Pada ranah pengetahuan diperoleh melalui penilaian yang dilakukan dalam bentuk pemberian tes tertulis (postest) berupa soal pilihan ganda. Ranah keterampilan diperoleh melalui penilaian yang dilakukan dalam bentuk observasi kinerja pada saat proses pembelajaran yang sedang berlangsung dengan 4 aspek penilaian yaitu menyiapkan alat dan bahan, melakukan percobaan, menulis hasil pengamatan dan mempresentasikan hasil percobaan. Dan ranah sikap diperoleh melalui penilaian yang dilakukan dalam bentuk observasi terhadap sikap dan perilaku selama proses pembelajaran yang sedang berlangsung meliputi pengamatan sikap jujur, disiplin, tanggung jawab dan gotong royong. Analisis persentase ketuntasan hasil belajar klasikal siswa pada siklus I dan siklus II dapat dilihat pada Tabel 2.

Tabel 2. Ketuntasan Belajar Siswa Klasikal Siklus I dan Siklus II

\begin{tabular}{|c|c|c|c|c|c|c|}
\hline Siklus & Hasil belajar tiap ranah & $\begin{array}{c}\text { Rata-rata } \\
\text { nilai tiap } \\
\text { ranah }\end{array}$ & $\begin{array}{c}\text { Jumlah } \\
\text { siswa } \\
\text { yang } \\
\text { tuntas }\end{array}$ & $\begin{array}{c}\text { Jumlah } \\
\text { siswa yang } \\
\text { tuntas } \\
\text { secara } \\
\text { keseluruha } \\
\text { n }\end{array}$ & $\begin{array}{c}\text { Persentas } \\
\text { e } \\
\text { ketuntasa } \\
\text { n belajar } \\
\text { klasikal }\end{array}$ & Kriteria \\
\hline \multirow{5}{*}{$\mathbf{I}$} & Hasil belajar pengetahuan & & & \multirow{5}{*}{29} & \multirow{5}{*}{$80,56 \%$} & \multirow{5}{*}{ Tidak Tuntas } \\
\hline & $(\geq 2,67)$ & 3,00 & 29 & & & \\
\hline & Hasil belajar keterampilan & & & & & \\
\hline & $(\geq 2,67)$ & 3,61 & 36 & & & \\
\hline & Hasil belajar sikap $(\geq 2,51)$ & 3,46 & 36 & & & \\
\hline \multirow{5}{*}{ II } & Hasil belajar pengetahuan & & & \multirow{5}{*}{33} & \multirow{5}{*}{$91,67 \%$} & \multirow{5}{*}{ Tuntas } \\
\hline & $(\geq 2,67)$ & 3,67 & 33 & & & \\
\hline & Hasil belajar keterampilan & & & & & \\
\hline & $(\geq 2,67)$ & 3,83 & 36 & & & \\
\hline & Hasil belajar sikap $(\geq 2,51)$ & 3,84 & 36 & & & \\
\hline
\end{tabular}

Berdasarkan Tabel 2. Pada siklus I dapat diketahui bahwa hasil belajar pengetahuan jumlah siswa yang memperoleh nilai $\geq 2,67$ adalah sebanyak 29 orang siswa dari 36 orang siswa yang mengikuti tes dalam bentuk postest, pada hasil belajar keterampilan jumlah siswa yang memperoleh nilai $\geq 2,67$ adalah sebanyak 36 orang siswa, dan pada hasil belajar sikap jumlah siswa yang berada dalam kategori baik atau $\geq 2,51$ adalah 
sebanyak 36 orang siswa dari 36 orang siswa. Dilihat dari ketiga aspek (pengetahuan, keterampilan dan sikap), siswa yang tuntas secara keseluruhan berjumlah 29 orang dengan presentase ketuntasan belajar secara klasikal 80,56 \%. Hal ini menunjukkan bahwa hasil belajar siswa dari pembelajaran yang telah dilaksanakan pada siklus I belum mencapai ketuntasan belajar klasikal karena jumlah siswa yang tuntas hanya berjumlah 29 orang dari 36 orang yang mengikuti kegiatan pembelajaran. Sedangkan kriteria ketuntasan secara klasikal pada mata pelajaran Biologi di SMA Plus Negeri 7 Kota Bengkulu untuk kelas XI adalah $85 \%$. Adapun refleksi untuk siklus I masih terdapat beberapa aspek pengamatan pada kriteria cukup, oleh sebab itu diperlukan langkah-langkah untuk memperbaiki kekurangan tersebut, sedangkan aspek-aspek yang telah terlaksana dengan baik perlu dipertahankan pada siklus II.

Pada siklus II diketahui bahwa hasil belajar pengetahuan jumlah siswa yang memperoleh nilai $\geq 2,67$ adalah sebanyak 33 orang siswa dari 36 orang siswa yang mengikuti tes dalam bentuk postest, pada hasil belajar keterampilan jumlah siswa yang memperoleh nilai $\geq 2,67$ adalah sebanyak 36 orang siswa dari 36 orang siswa, dan pada hasil belajar sikap jumlah siswa yang berada dalam kategori baik atau $\geq 2,51$ adalah sebanyak 36 orang siswa dari 36 orang siswa. Dilihat dari ketiga aspek (pengetahuan, keterampilan dan sikap), siswa yang tuntas secara keseluruhan berjumlah 33 orang dengan presentase ketuntasan belajar secara klasikal 91,67 \%. Hal ini menunjukkan bahwa pembelajaran yang dilaksanakan pada siklus II sudah mencapai kriteria tuntas dengan presentase ketuntasan belajar klasikal pada siklus II telah mencapai $85 \%$ dan sesuai dengan Kriteria Ketuntasan Minimal (KKM) mata pelajaran Biologi di SMA Plus Negeri 7 Kota Bengkulu. Adapun refleksi pada siklus II secara umum sudah terlaksanakan dengan baik jika dibandingkan pada siklus I. Hal ini dikarenakan observasi aktivitas guru dan siswa yang telah dilakukan sudah tidak ditemukan lagi kegiatan yang kurang terlaksana dengan baik.

\section{Deskripsi Aktivitas Mengajar Guru dan Belajar Siswa}

Berdasarkan hasil pengamatan proses pembelajar dengan model pembelajaran inkuiri pada aktivitas guru dan aktivitas siswa secara umum pada kedua siklus pelaksanaan pembelajaran dikategorikan baik. Peningkatan aktivitas guru disetiap siklus ditunjukkan pada Grafik 1.

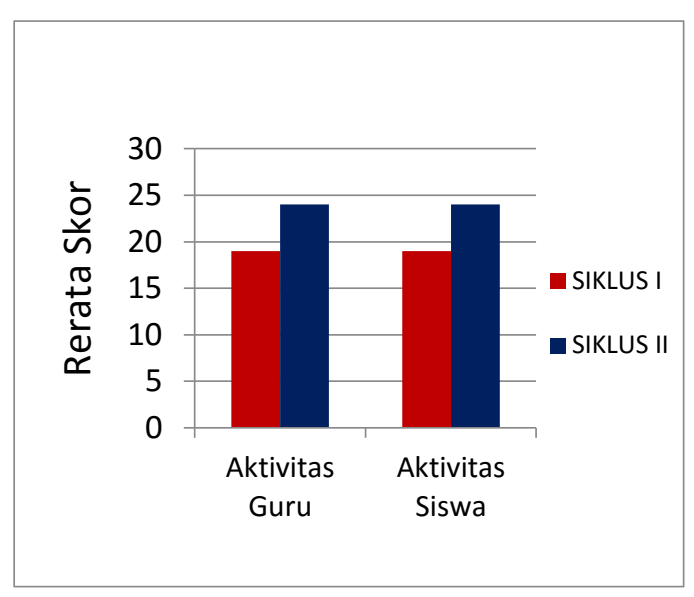

\section{Grafik 1. Aktivitas Guru dan Aktivitas Siswa Siklus I dan II}

Dari grafik 1. diatas, dapat dilihat bahwa terjadi peningkatan aktivitas guru dan aktivitas siswa ini dikarenakan refleksi yang dilakukan pada siklus I. Hal ini sesuai dengan pernyataan yang dikemukakan oleh Seniwati (2015) bahwa terjadinya peningkatan aktivitas siswa dari siklus I ke siklus II menunjukkan bahwa sebagian besar siswa memiliki perhatian yang besar dalam mata pelajaran biologi, khususnya dalam proses pembelajaran menggunakan model inkuiri.

\section{Hasil Belajar dari Siklus I ke Siklus II}

Pada proses pembelajaran yang dilalui selama dua siklus pembelajaran ini tidak hanya terdapat peningkatan aktivitas guru dan aktivitas siswa saja, melainkan juga terdapat peningkatan pada hasil belajar siswa yang mencakup aspek kognitif, afektif dan 
psikomotor. Peningkatan proses pembelajaran yang terjadi sejalan dengan peningkatan hasil belajar yang dicapai oleh siswa. Hal ini sesuai dengan hasil penelitian Seniwati (2015) yang menunjukkan bahwa terjadi peningkatan aktivitas dan hasil belajar biologi siswa melalui penerapan model pembelajaran inkuiri.

Pada siklus I diperoleh persentase ketuntasan belajar klasikal yaitu $80,56 \%$. Hal ini menunjukkan bahwa pembelajaran yang telah dilaksanakan pada siklus I belum mencapai kriteria tuntas dengan presentase ketuntasan belajar klasikal pada siklus I yaitu 85\%. Kemudian setelah dilakukan refleksi pada proses pembelajaran di siklus I diperoleh hasil ketuntasan belajar klasikal siswa pada siklus II yaitu 91,67\%. Hal ini menunjukkan bahwa pembelajaran yang telah dilaksanakan pada siklus II sudah mencapai kriteria tuntas dengan presentase ketuntasan belajar klasikal pada siklus II telah mencapai $85 \%$ dan sesuai dengan Kriteria Ketuntasan Minimal (KKM) mata pelajaran Biologi di SMA Plus Negeri 7 Kota Bengkulu. Hal ini sejalan dengan yang dikemukakan oleh Hosnan (2014) bahwa hakikat belajar adalah adanya perubahan tingkah laku yang merupakan sebagai hasil belajar yang mencakup hampir semua kecakapan, keterampilan, pengetahuan, kebiasaan, keinginan, motivasi dan sikap yang disadari dan disengaja.

Berdasarkan pada hasil penelitian tersebut menunjukkan bahwa model pembelajaran inkuiri sangat baik diterapkan di sekolah karena siswa mendapatkan pengalaman belajar secara langsung dan dapat melakukan percobaan secara mandiri tetapi tetap pada jalur ilmunya sedangkan guru sebagai fasilitator dan pembimbing siswanya dalam proses pembelajaran sehingga dapat meningkatkan aktivitas dan hasil belajar biologi siswa.

\section{PENUTUP}

\section{Kesimpulan}

Berdasarkan hasil penelitian dan pembahasan, diperoleh kesimpulan sebagai berikut:
1) Pembelajaran dengan menerapkan model pembelajaran inkuiri pada mata pelajaran biologi materi sistem ekskresi dapat meningkatkan aktivitas guru dan siswa di kelas XI IPA 6 SMA Plus Negeri 7 Kota Bengkulu. Hal ini dapat dilihat dari hasil observasi aktivitas guru siklus I diperoleh skor rata-rata 19 (cukup) dan siklus II menjadi 24 (baik). Sedangkan hasil observasi aktivitas siswa siklus I diperoleh skor rata-rata 19 (cukup) dan siklus II menjadi 24 (baik).

2) Pembelajaran dengan menerapkan model pembelajaran inkuiri dalam proses pembelajaran pada materi sistem ekskresi manusia dapat meningkatkan hasil belajar siswa di kelas XI IPA 6 SMA Plus Negeri 7 Kota Bengkulu. Hal tersebut ditunjukkan dengan meningkatnya presentase ketuntasan belajar klasikal siklus I adalah $80,56 \%$ dan siklus II adalah 91,67\%.

\section{Saran}

1) Diharapkan kepada guru mata pelajaran biologi dapat menggunakan model pembelajaran inkuiri sebagai salah satu alternatif dalam pembelajaran untuk diterapkan pada pembelajaran biologi sebagai salah satu upaya meningkatkan hasil belajar siswa.

2) Untuk peneliti selanjutnya diharapkan dalam proses pembelajaran yang menerapkan model pembelajaran inkuiri guru harus lebih memperhatikan alokasi waktu yang telah ditetapkan, agar seluruh tahapan dapat tercapai.

\section{DAFTAR PUSTAKA}

Abidin, Yunus. 2014. Desain Sistem Pembelajaran dalam Konteks Kurikulum 2013. Bandung: Refika Aditama

Anam, Khoirul. 2016. Pembelajaran Berbasis Inkuiri Metode dan Aplikasi. Yogyakarta: Pustaka Belajar

Arikunto, Suharsimi. 2010. Prosedur Penelitian (Suatu Pendekatan Praktik). Jakarta: PT Rineka Cipta 
Arikunto, Suharsimi, dkk. 2014. Penelitian Tindakan Kelas. Jakarta: Bumi Aksara

Fadlillah, M. 2014. Implementasi Kurikulum 2013 dalam Pembelajaran SD/MI, SMP/MTS dan SMA/MA. Yogyakarta: Ar - Ruzz Media

Hosnan, M. 2014. Pendekatan Saintifik dan Kontekstual dalam Pembelajaran Abad 21. Bogor: Ghalia Indonesia

Kurniasih, I dan S, Berlin. 2014. Sukses Mengimplementasikan Kurikulum 2013. Jakarta: Kata Pena

Rusman. 2011. Model - Model Pembelajaran Mengembangkan Profesionalisme Guru. Jakarta: PT Raja Grafindo Persada

Seniwati. 2015. Peningkatan Aktivitas, Sikap dan Hasil Belajar Biologi melalui Penerapan Model Pembelajaran Inkuiri pada Siwa Kelas X1 SMA Negeri 1 Bontonompo. Jurnal Nalar Pendididkan, (Online), Vol 3, No. 1, (http://oaji.net/articles/2015/2196-

1436547147.pdf, diakses 19 Januari 2017)

Sudjana, Nana. 2011. Penilaian Hasil Proses Belajar Mengajar. Bandung: PT Remaja Rosdakarya

Trianto. 2011. Panduan Lengkap Penelitian Tindakan Kelas (Classroom Action Researchl) Teori dan Praktik. Jakarta: Prestasi Pustakaraya 